\title{
SPECIFIC NATURE OF EVALUATIVE SPEECH ACTS
}

\author{
Ganna Prihodko \\ Zaporizhzhia National University, Zaporizhzhia, Ukraine \\ anna.prikhodko.55@gmail.com
}

\begin{abstract}
The article discusses the issues connected with the analysis of appearance of the evaluation in the utterance. Particular attention is paid to the illocutionary and perlocutionary effect of evaluative speech acts. The speech act is viewed in the paper as the minimum unit of communication. The structure of the speech act includes four levels: locution, proposition, illocution and perlocution. In the evaluative speech acts semantic basis serves as the category of evaluation. Considering semantic and pragmatic properties of the object of our study, the author proposes to distinguish the following types of evaluative speech acts: 1) focus on the subject; 2) focus on the object. Among evaluative speech acts, oriented on the object, the author singles out proper evaluative speech acts (praise, condemnation) and emotional evaluation speech acts (admiration, anger, respect). This approach is based on the fact that evaluative verbs are direct representatives of illocutionary intention of evaluative speech acts. The author comes to the conclusion that the classification of evaluative speech acts can rely on semantic and pragmatic features of evaluative verbs.
\end{abstract}

Keywords: evaluation; speech act; locution; illocution; perlocution.

\section{Introduction}

The values' model of the world is arranged through the system of the cultural universals, i.e. a set of interconnected universal notions, which can be expressed by language means in different types of speech acts.

The study of speech activity in the context of modern linguistic directions such as psycholinguistic, cognitive, and pragmatic ones allows us to look at the language phenomena in the dynamics, due to the laws of speech thinking and pragmatic factors of speech communication.

Taking part in acts of communication, we either perceive what is said or produce utterances by ourselves. The perception of the latter is a complex process that presupposes the use of a wide range of information. Nonetheless, the study of all known methods of expression and transmission of information can be carried out, according to van Dijk (1989), in terms of knowledge, having "a more general character: understanding is inevitably based on more general concepts, categories, rules and strategies" (p. 16).

The speech act is regarded as the minimal unit of speech communication. It is common knowledge that the term "speech act" is interpreted by researchers in different ways. It is used both to designate its structural components, and to indicate the speech act in general. In the structure of the speech act four levels locution, proposition, illocution and perlocution - can be distinguished. Locution is the act of proclaiming a sentence; illocution is the realisation of the speaker's communicative intention; perlocution is the influence that this utterance produces on the addressee (Paducheva, 1985, p. 23; Arutyunova, 2012). This implies not the fact of the addressee's understanding of the content of the statement, but those changes in the addressee's state or behaviour, which are the result of this understanding.

Different illocutionary acts often aim to achieve a certain perlocutive effect (for example, the message of something or a statement try to convince the interlocutor in something, a question, a request or an order directed to the corresponding verbal or non-verbal reaction of the addressee (Bulygina, Shmelev, 1997, p. 249).

The question of inclusion or not inclusion of perlocution into the structure of the speech act is debatable in the theory of speech acts. Some scholars consider that the speech act must be clearly distinguished from the perlocution, because the latter may not be achieved by linguistic means (Austin, 1986, p. 24). Other researchers regard perlocution as an obligatory component of the speech act's structure, emphasising that without achieving the perlocutionary effect the speech act cannot be considered complete (Bulygina, Shmelev, 1997, p.248). We adhere to the idea that the inclusion of perlocution in the structure of the speech act is logically correct and appropriate: if the speech act is understood as speech action, then it is logical to analyse the results of this action (perlocution). In addition to the abovementioned components, the structure of the speech act includes the utterance itself.

It is necessary to emphasise that the essence of the speech act is in the following: in addition to expressing its own content, the sentence can perform some actions: it can claim something, ask about anything, order, warn, promise, etc. (Halliday \& Matthiessen, 2014; Pocheptsov, 2009). A compulsory component of any speech act is the communicative intention: if the addressee in the process of perceiving the speech act correctly determines the communicative intention of the addresser, then we can speak about the successful implementation of the speech act.

While producing an utterance, the speakers inevitably apply to paradigmatic means of the language, though there are a number of other things we can do with words. We can inquire about something, ask 
questions, make orders and promises, express gratitude or offer apologies, etc. Besides, almost any speech act can be qualified as the actualisation of several acts at once, marked by various aspects of the speaker's intention. Consequently, in the speech act it is possible to distinguish the act of uttering something, what the speaker does while saying it, for instance, inquiring or threatening, as well as the effect the speaker is attempting to produce on the recipient.

The notion of speech act as a unit of verbal communication was introduced into linguistics by the scientists of the Oxford School (Austin, 1975; Searle, 1976) and their followers (Grice, 1975; Arutyunova, 2012). The theory of speech acts remains in the focus of linguists since it enables them to study the communicative activity from the functional standpoint, i.e. stressing the importance of illocutionary function of communication. The type of speech acts is traditionally viewed as a model of a homogeneous group of speech acts, characterised by a number of common features that reflect a particular aspect of human communication (Bezugla, Romanchenko, 2013, pp. 32-34).

It generally accepted that speech acts are the acts of communication. As is known, to communicate is to convey a certain attitude to what is said, to the interlocutor, to the communicative situation, etc., and, consequently, the type of the performed speech act corresponds to the type of attitude it expresses. For instance, a statement usually expresses a certain viewpoint, a request conveys the speaker's need or desire, while an apology communicates regret. Thus, a speech act, being in fact the act of communication, can be viewed as successful when the recipient recognises and perceives the speaker's attitude expressed in the utterance.

The evaluative utterance occupies one of the significant places in the theory of speech acts. Like any speech act, it is aimed at solving specific problems of communication considering its functional and semantic properties, as well as phenomena of reflection of different aspects of existing reality in the individual's thinking-and-speaking activities (Bezugla, Romanchenko, 2013, pp. 32-33; Myroniuk, 2017, p. 103).

In view of this, the aim of the article is to systematise typical features of evaluative speech acts by means of defining their place and role in the process of communication.

The choice of methods and techniques, being of a complex character, is conditioned by the research aim and theoretical orientation of the paper. They incorporate ideas of the cognitive theory and pragmalinguistics. The analysis of speech act is applied for studying pragmatic properties of the utterances containing evaluative concepts; the descriptive method is used to characterise the structure of evaluative speech acts.

\section{Evaluative Speech Acts in the Process of Communication}

Viewed as the speech act of one of the participants of the process of communication, an evaluative utterance reflects the pragmatic nature of the interaction practice, thereby serving as an indicator of partners' communicative activity (Prihodko, 2016, p. 277). However, being a component of one of the speakers' communicative activity, an evaluative utterance doesn't fully reflect the entire process of communication, only representing a definite single step of participants of this communication, intended to achieve a definite communicative aim.

To define the specific features of the utterance with evaluative potential as well as find out its ability to present important characteristics of the act of communication, it is necessary, first of all, to clarify where and how an evaluative utterance can reveal its properties as a part of communicative activity. The analysis of evaluative speech acts was performed in accordance with the known classification of speech acts, proposed by Searle (Searle, 1976), who singled out basic types of speech acts.

Considering the evaluative semantics expressed in the speaker's attitude as the concepts of "good / bad", the main types of evaluative speech acts include condemnation and approval, while other types, preserving this invariant meaning, can realise different illocutionary functions according to the intensity of the expressed evaluation or the degree of the perlocutionary influence on the addressee. The illocutionary force may not be conveyed explicitly by language means. It should be emphasised that the same propositional content in different communicative environment can represent different speech acts.

Speech act, as it was outlined above, is generally recognised as the unit of communication. The study of the speech act as an independent and structurally closed unit serves the basis for the analysis of separate speech acts, namely evaluative ones, in order to comprehend the entire variety of properties of the human language and the regularities of organisation of the individual's speech activity.

Pragmalinguistic studies distinguish speech acts whose semantics does not coincide with their illocutionary function. Such speech acts are called indirect ones (Pocheptsov, 2009). Searle, examining the difference between direct and indirect speech acts, singled out three types of statements - metaphoric, ironic and indirect speech acts - which are opposed to "literal statements" (Searle, 1990, p. 308). 
The scholar states that the problem of the metaphor functioning presents a particular case of a more general problem, namely, the explanation of the difference between the speaker's thought and the meaning of a sentence or a word. In other words, the problem lies in the explanation of how it is possible to say one thing in terms of something else, how it is possible to tell something when both the speaker and the listener know that the meaning of the uttered sentence does not correspond exactly to what he/she meant. Other cases representing the gap between what is said and what is meant are the irony and indirect speech acts.

In pragmatics, the scholars distinguish one more type of such communicative "discrepancy". Unlike the above-mentioned cases, which are marked by inconsistency of the "said" and "significant", these speech situations are characterised by "indirect addressing" of the statement. In such cases, the speaker, addressing the listener, actually addresses this information to the present third person. Thus, one can speak of the existence of a "false" and "true" listener. In our opinion, the reasons for the occurrence of such pragmatically unusual situations are social and ethical factors, as well as the speaker's speech strategy and tactics, specified by definite communicative circumstances.

\section{Category of Evaluation as the Basis of Evaluative Speech Acts}

In the focus of modern researchers, as we have already mentioned, there are issues of pragmatics, the problems of the personality of the communicant, the means of the most adequate expression of various kinds of meanings, including evaluative ones (Vol'f, 2009). The idea of the classification and systematisation of speech acts in the so-called "communicative-semantic fields" and "communicative-semantic groups" is very efficient in the theory of speech acts. The communicative-semantic group is understood as "the set of sentences of the given language, members of which have a certain illocutionary purpose, which causes the expression of a certain speech intention, contain indicators of their illocutionary purpose and belong to standard means of verbal communication, reflecting the pragmatic synonymy of sentences and paradigmatic relations between various ways of expressing speech intentions" (Zhulmanova, 1999, p. 3).

The language model of the world with a word being its basic unit is an important component of the national culture. The language model coincides with the language system, its units and their interrelations as well as reflects the system values typical of the speaking community in general and the individual language speakers in particular. The value being a category of logic is contrasted with a linguistic category of evaluation.

In evaluative speech acts, the semantic basis is the category of evaluation. Evaluation is defined as the speaker's objective or subjective attitude to a certain object, which is explicitly or explicitly expressed by language means (Prihodko, 2016, p. 17). Critically reflecting the place that Searle assigns to evaluative speech acts in the general typology of speech acts, Vol'f writes that "...the class of expressiveness" must be understood much broader than it is proposed by Searle. She offers to add to this class utterances of apology, gratitude, congratulations which are conditioned by social conventions, and evaluative utterances that belong to individuals having their illocutionary purpose to express the emotional state or produce an emotional impact on the listener. These utterances are based on approval and condemnation in a broad sense of a word (Vol'f, 2009, p. 167).

As an anthropocentric category, evaluation depends on the system of norms and principles of a language community and is inseparable from the national specificity of the perception of the world by language speakers. Evaluation is characterised by a number of criteria, which are reflected in national culture and which gain a particular value importance expressed in the language in its evaluative speech acts.

The identification of units of speech communication that have national-cultural specificity and the introduction of the concept of national-cultural stereotype as a unit of analysis is conceptually important. Each ethnos has its own national and cultural stereotypes that determine the language behaviour. In our opinion, the comparison of stereotypes of representatives of different nations can reveal the national features of speech behaviour, cultural traditions in the evaluative activities.

The success of any speech act depends on observing the Cooperative principle and the Politeness Principle (Grice, 1975; Leech, 1983). It is especially important for the evaluative speech act since compliance with these maxims will ensure a proper understanding of the meaning of evaluative utterances.

The indispensable factor of stylistic marking in the process of communication is a speech situation. It can be defined as the social context of interaction. The speech situation is determined by different situational factors that are the elements of speech situation. They are the participants (speaker and addressee) and their social relations; the topic and the purpose of communication; the mode of linguistic expression: spoken or written language. Simultaneously these factors constitute the speech situation. Considering the aspects of the speech situation, the interlocutors choose language means which they consider appropriate for a certain speech situation. 
The prominent linguist Teliya (1986) presents a set of speech situations, which, in her opinion, are basic for the social-role typology. First of all, she highlights a "neutral stylistic situation", or "the language standard". It means that the social relations of interlocutors do not add any "traces" to the type of speech (from official to informal communication) (Teliya, 1986). In addition to neutral speech, we can distinguish an informal situation: social relations of speakers are defined as (1) familiar, their role status can be defined as the attitude of "close acquaintance", role position is qualified as "equal"; (2) roughly familiar, when a close acquaintance gives grounds for the very close familiar relations, and the role position is of no importance for the personality or to its merits.

In view of this, linguists speak about the evaluative speech act as its basic type, which includes a variety of speech acts such as approval, condemnation, censure, praise, flattery, compliment (Lulu, 2017; White, 2016). Scholars also differentiate between written evaluative speech acts: characteristics, reviews, expert conclusions; oral: for example, jubilee speech, etc.

Some researchers studied semantic and pragmatic specificity of means expressing evaluation and suggested the following gradation scheme of evaluation intensity (Prihodko, 2016; Wang and $\mathrm{Xu}, 2013$ ) within the evaluative speech acts. The speech acts of approval and disapproval (with the semes "good / bad") are the core of evaluative speech acts. They are explicated with the help of different language means. According to the degree of intensity of positive evaluation, we distinguish the evaluative acts of praise (having the seme "good enough"). The intensity gradation scheme closes with positive evaluative speech having the meaning of admiration (i.e. with the seme "very good").

The range of degrees of negative evaluation intensity begins with the speech acts of disapproval, followed by evaluative speech acts of condemnation (having the seme "rather bad"). The chain of intensity of negative evaluations in the core of evaluative semantics closes with speech acts of indignation (with the seme "very bad"). The evaluative speech acts of surprise and conviction are peripheral ones in this scheme.

\section{Conclusions}

To sum up, our study provides an insight into the theory of speech acts. Taking into account semantic and pragmatic properties of the object of our study, we propose to distinguish the following types of evaluative speech acts: 1) subject-oriented and 2) object-oriented ones. They can be divided into proper evaluative speech acts (praise, condemnation) and emotionally-coloured evaluative speech acts (admiration, indignation, respect). This approach is based on the fact that verbs with evaluative meaning are direct verbal representatives of the illocutionary intention of evaluative speech acts. Thus, we consider it reasonable that the classification of evaluative speech acts should be based on semantic and pragmatic features of evaluative verbs.

It is clear that a problem of evaluative speech acts is a multifaceted phenomenon that should be studied from different angles. In this article we have presented the general analysis of the problem of evaluative speech acts in pragmalinguistics. Value is a positive or negative significance of the objects of the surrounding world for the speaking community. This significance is determined not by the objects' properties as such, but by their role in the life of an individual speaker and in the life of the speaking community in general. It displays the deep cognitive nature of evaluation. In view of this, a further research grounded on the correlation of pragmatic and cognitive approaches to the study of evaluation can be fruitful. Our future research will be aimed at studying national-cultural and gender-related features of evaluative speech acts and their manipulative influence.

\section{References:}

Arutyunova, N. (2012). Logicheskij analiz yazyka. Adresatsiya diskursa [Logical analysis of the language. Discourse addressing]. Moscow, Russia: Indrik.

Austin, J. (1975). How to do things with words $\left(2^{\text {nd }}\right.$ ed.). Cambridge, USA: Harvard University Press. http://dx.doi.org/10.1093/acprof:oso/9780198245537.001.0001

Bezugla, L. \& Romanchenko, O. (2013). Lingvpragmatuka duskriminatsii u publitsistuchnomu diskursi [Linguopragmatics of discrimination in publicistic discourse]. Kharkiv, Ukraine: FOP Lusenko I. B.

Bulygina, T. \& Shmelev, A. (1997). Yazykovaya kontseptualizatsiya mira (na materiale russky grammatiki) [Language conceptualization of the world (on the basis of Russian grammar)]. Moscow, Russia: Yazyki russky kulturu.

Dijk, T. (1989). Yazyk. Poznaniye. Kommunikatsiya. [Language. Cognition. Communication]. Moscow, Russia: Progress.

Grice, H. (1975). Logic and conversation. In P. Cole \& J. Morgan (Eds.), Speech Acts (pp. 41-58). New York, USA: Academic Press.

Halliday, M., \& Matthiessen, C. (2014). Halliday's introduction to functional grammar (4th ed.). London, England and New York, USA: Routledge.

Leech, G. (1983). Principles of pragmatics. London, England: Longman.

Lulu, L. (2017). Application of Cooperative Principle and Politeness Principle in Class Question-answer Process. Theory and Practice in Language Studies, 7 (7), 563-569. http://dx.doi.org/10.17507/tpls.0707.10

Myroniuk, T. (2017). The Category of Evaluation in Political Discourse. Advanced Education, 8, 128-137. http://dx.doi.org/10.20535/2410-8286.108550. 
Paducheva, E. (1985). Vuskazyvaniye I ego sootnesenost's deystvitel'nostyu [Utterance and its correlation with reality]. Moscow, Russia: Nauka.

Pocheptsov, G. (2009). Izbrannye trudy po lingvistike [Selected works in linguistics]. Kharkiv, Ukraine: V.N. Karazin Kharkiv national university.

Prihodko, A. (2016). Cognitive-communicative organisation of the evaluative frame. Lege Artis, 1(1), 275-308. http://dx.doi.org/10.1515/lart-2016-0006

Prihodko, A. (2016). Katehoriia otsinky $v$ konteksti zminy linhvistychnykh paradyhm [The category of evaluation in the context of the change of linguistic paradigms]. Zaporizhzhia, Ukraine: Kruhozir.

Searle, J. (1976). A classification of illocutionary acts. Language in society, 5(1), 1-23. http://dx.doi.org/10.1017/s0047404500006837

Searle, J. (1990). Metafora [Metaphor]. Moscow, Russia: Progress.

Teliya, V. (1986). Konnotativnuy aspekt semantiki nminativnuh edenits. [Connotative aspect of semantics of nominative units]. Moscow, Russia: Nauka.

Vol'f, E. (2009). Funktsional'naya semantika otsenki [Functional semantics of evaluation] ( $3^{\mathrm{d}}$ ed.). Moscow, Russia: Editorial URSS.

Wang, Y., \& Xu, J. (2013). The interrelation between evaluative categories and evaluated items. Linguistics and the Human sciences, 8(1), 29-61. http://dx.doi.org/10.1558/lhs.v8i1.29

Zhulmanova, I. (1999). Kommunikativno-semanticheskiye gruppu v raznostrukturnuh yazykah [Communicative-semantic groups in the difference-structured languages]. PhD thesis, Almaty.

Received: April 09, 2018

Accepted: May 18, 2018 